\title{
The $\boldsymbol{N}$-Acetylhexosaminidase Components of the Ram Testis and Epididymis
}

\author{
By SARAH BULLOCK and BRYAN WINCHESTER \\ Department of Biochemistry, Queen Elizabeth College, University of London, \\ Campden Hill, London W8 7AH, U.K.
}

(Received 20 February 1973)

\begin{abstract}
Three and four $N$-acetylhexosaminidase components, from ram testis and epididymis respectively, have been separated by ion-exchange chromatography on DEAE-cellulose. Although they all have the same molecular weight (approx. 140000) and very similar catalytic properties towards the synthetic substrates, 4-methylumbelliferyl $N$-acetyl- $\beta$ glucosaminide and $N$-acetyl- $\beta$-galactosaminide, isoelectric focusing of the individual components showed that each had a distinct pI value. Isoelectric focusing has also been used to demonstrate the occurrence of multiple forms in ejaculated ram semen.
\end{abstract}

The presence of high amounts of $N$-acetyl- $\beta$ glucosaminidase $(\beta$-2-acetamido-2-deoxy-D-glucoside acetamidodeoxyglucohydrolase, EC 3.2.1.30) in the mammalian male genital tract is well established (Conchie \& Mann, 1957; Conchie et al., 1959a,b). Although this enzyme is believed to be involved in the degradation of amino sugar-containing mucosubstances, a specific function is not yet apparent in the reproductive tract. The histochemical studies by Pugh \& Walker (1961) in the rat suggest that the activity is not distributed uniformly through the tract but is localized in specific regions and cells. Findlay \& Levvy (1960) have shown that the activity also varies greatly along the length of the pig epididymis. Multiple forms of the enzyme have been demonstrated in the pig epididymis (Leaback \& Walker, 1967; Vikha et al., 1971) and the ram testis (Caygill et al., 1966) by ion-exchange chromatography. It has also been shown by isoelectric focusing that multiple forms of the enzyme occur in the ram testis and epididymis but that different forms predominate in the two tissues (Winchester, 1971). The concentration of the predominant epididymal component varied greatly along the length of the epididymis. Those sections of the epididymis that were found to be richest in enzyme activity are also those in which the lumen has been shown to be crowded with spermatozoa (Nicander, 1958). Thus the very high concentration of the predominant component in these sections may be associated with the presence of spermatozoa. In this paper the heterogeneity of the $N$-acetylhexosaminidase activity in the ram testis and epididymis has been examined further.

\section{Materials and Methods}

\section{Tissue}

Frozen sheep testes with epididymes intact were obtained from Gland Supplies Ltd., Manchester,
U.K. and kept frozen at $-15^{\circ} \mathrm{C}$ until required. After removal of the skins the testes and epididymes were separated and $25 \%(\mathrm{w} / \mathrm{v})$ homogenates of the organs were prepared separately in $50 \mathrm{~mm}$-sodium citrate buffer, pH5.0, by using an MSE top-drive homogenizer. The homogenates were allowed to stand at $4^{\circ} \mathrm{C}$ for $4-5 \mathrm{~h}$ before centrifugation for $15 \mathrm{~min}$ at $4^{\circ} \mathrm{C}$ and $3000 \mathrm{~g}\left(r_{\mathrm{av}} .10 \mathrm{~cm}\right)$. Material was precipitated from the supernatants at $4^{\circ} \mathrm{C}$ in a stepwise manner by increasing the concentration of $\left(\mathrm{NH}_{4}\right)_{2} \mathrm{SO}_{4}$. At each stage of the fractionation the solutions were allowed to stand for $10-12 \mathrm{~h}$ before centrifugation for $15 \mathrm{~min}$ at $3000 \mathrm{~g}$. Each precipitate was redissolved in $200 \mathrm{ml}$ of $10 \mathrm{~mm}$-sodium phosphate buffer, $\mathrm{pH} 7.0$.

Frozen, pooled, ejaculated ram semen was a gift from Dr. J. C. Boursnell, Agricultural Research Council Unit of Reproductive Physiology and Biochemistry, Cambridge, Cambs., U.K. Thawed whole semen was dispersed in $10 \mathrm{vol}$. of $0.9 \%(w / v) ~ N a C l$ and sonicated in an MSE $100 \mathrm{~W}$ ultrasonic disintegrator for $2 \mathrm{~min}$ with a probe amplitude of $7 \mu \mathrm{m}$. Cell debris was removed from the sonicated sample by centrifugation for $30 \mathrm{~min}$ at $2500 \mathrm{~g}$. The supernatant was analysed by isoelectric focusing.

\section{Enzyme assays}

The fluorimetric assay procedure of Leaback \& Walker (1961) was employed to determine $N$-acetyl$\beta$-glucosaminidase activity and adapted for the assay of $N$-acetyl- $\beta$-galactosaminidase with 4-methylumbelliferyl $N$-acetyl- $\beta$-galactosaminide (KochLight Laboratories Ltd., Colnbrook, Bucks., U.K.). Routine assays were carried out in $50 \mathrm{~mm}$-sodium citrate buffer, $\mathrm{pH} 5.0$ at $37^{\circ} \mathrm{C}$. One unit of activity is that amount of enzyme which transforms $1 \mu \mathrm{mol}$ of substrate/min under these conditions. The kinetic parameters, $K_{m}$ and ' $V$, were determined by the method of Lineweaver \& Burk (1934). The Mcllvaine (1921) phosphate-citrate buffer system was used in

Vol. 133 
these experiments and in the determination of $\mathrm{pH}$ optima.

\section{Determination of protein}

Protein was measured by the Folin method (Lowry et al., 1951) with bovine serum albumin as a standard.

\section{Gel filtration}

The material precipitated from the tissue extracts between 30 and $40 \%$ saturation with $\left(\mathrm{NH}_{4}\right)_{2} \mathrm{SO}_{4}$ was redissolved in $10 \mathrm{~mm}$-sodium phosphate buffer, $\mathrm{pH} 7.0$, and passed through a column $(75 \mathrm{~cm} \times 5.0 \mathrm{~cm}$ diam.) of Sephadex G-25 [Pharmacia (G.B.) Ltd., London W.13, U.K.] equilibrated in the same buffer. This process removed the $\left(\mathrm{NH}_{4}\right)_{2} \mathrm{SO}_{4}$ from the enzymic material, which was recovered in the starting buffer for the ion-exchange chromatography.

The molecular weights of the purified enzymic components were estimated by gel filtration on columns of Sephadex G-100 $(34.5 \mathrm{~cm} \times 2.5 \mathrm{~cm}$ diam. $)$ and Sephadex G-150 $(32 \mathrm{~cm} \times 2.5 \mathrm{~cm}$ diam. $)$ in $0.2 \mathrm{M}-$ sodium phosphate buffer, pH7.0. Control experiments were performed in $50 \mathrm{~mm}$-sodium phosphate buffer, pH7.0, to investigate whether the ionic strength affected the elution behaviour of the enzymic components. Estimates of the molecular weights were also made by using a column $(30 \mathrm{~cm} \times 2.5 \mathrm{~cm}$ diam. packed with Bio-Gel P-150 (Bio-Rad Laboratories Ltd., St. Albans, Herts., U.K.). Equilibration and elution was again with $0.2 \mathrm{M}$-sodium phosphate buffer, pH7.0. The columns were calibrated with the following standards (mol.wt.): cytochrome $c$ 12400), bovine serum albumin (67000) and bovine $\gamma$-globulin $[160000$; Sigma (London) Chemical Co., London S.W.6, U.K.], bovine intestinal alkaline phosphatase [130000; MilesSeravac (Pty) Ltd., Maidenhead, Berks., U.K.] and Blue Dextran [Pharmacia (G.B.) Ltd.]. Partition coefficients between the liquid and gel phase $\left(K_{\text {av. }}\right)$ were calculated for each standard from two to five independent experiments:

$$
K_{\mathrm{av} .}=\frac{V_{\mathrm{e}}-V_{0}}{V_{\mathrm{t}}-V_{0}}
$$

where $V_{\mathrm{e}}$ is the elution volume of the standard, $V_{0}$ the void volume of the column and $V_{\mathrm{t}}$ the total volume of the gel bed. A plot of the partition coefficients of the standards against the logarithms of their molecular weights was used to estimate the molecular weight of the $N$-acetylhexosaminidase.

In all the gel-filtration, ion-exchange-chromatography and isoelectric-focusing experiments fractions were collected by using a BTL Chromapump and Chromafrac (Baird \& Tatlock Ltd., Chadwell Heath, Essex, U.K.). The column eluents were monitored continuously at $280 \mathrm{~nm}$ by using an LKB Uvicord II absorptiometer (LKB Instruments Ltd., London S.E.20, U.K.) or a Locarte u.v. monitor (Locarte Co., London S.W.7, U.K.).

\section{Ion-exchange chromatography}

The testicular and epididymal $\mathrm{N}$-acetylhexosaminidase preparations from which the $\left(\mathrm{NH}_{4}\right)_{2} \mathrm{SO}_{4}$ had been removed by gel filtration were analysed by ion-exchange chromatography on DEAE-cellulose (Whatman DE-32). The DEAE-cellulose was equilibrated in 10mM-sodium phosphate buffer, $\mathrm{pH} 7.0$, and packed in columns $(35 \mathrm{~cm} \times 2.5 \mathrm{~cm}$ diam., $30 \mathrm{~cm} \times$ $1.5 \mathrm{~cm}$ diam. or $5 \mathrm{~cm} \times 0.8 \mathrm{~cm}$ diam.) according to the size of the sample. Elution was started with the equilibration buffer and continued with a linear buffer concentration gradient from $10 \mathrm{mM}$ - to $200 \mathrm{~mm}$ sodium phosphate buffer, at a constant $\mathrm{pH}$ 7.0. The gradient was followed by measuring the conductivity of the fractions with a conductivity measuring bridge type M.C.3 [Electronic Switchgear (London) Ltd., Hitchin, Herts., U.K.]. When a component separated by ion-exchange chromatography was rechromatographed it was dialysed against the $10 \mathrm{~mm}$ buffer before application to the second column.

\section{Isoelectric focusing}

Samples were analysed by isoelectric focusing in an Ampholine type 8100 column (LKB Instruments Ltd.) at $5^{\circ} \mathrm{C}$ as described by Vesterberg \& Svensson (1966) and Winchester (1971). pH gradients were established by using the appropriate ranges of synthetic ampholytes (LKB Instruments Ltd.) in a concentration of approx. $0.83 \%(w / v)$. If necessary low-molecular-weight electrolytes were removed from protein samples before focusing by dialysis against $1 \%(w / v)$ glycine adjusted to $\mathrm{pH} 6.0$. In some instances samples were concentrated by dialysis against polyethylene glycol 4000P (Shell Chemicals Ltd., London S.E.1, U.K.) before analysis. The $N$-acetyl$\beta$-glucosaminidase components separated by ionexchange chromatography were focused as soon as possible after separation, preferably without being stored frozen. Electrofocusing was started with a power of $250 \mathrm{~V}$ and $2-3 \mathrm{~mA}$ and was continued until the current fell to a steady low value of $0.4-0.5 \mathrm{~mA}$ at $500 \mathrm{~V}$, a period of $50-60 \mathrm{~h}$ usually. The column was emptied at a rate of $60 \mathrm{ml} / \mathrm{h}$ and the effluent monitored continuously at $280 \mathrm{~nm}$. The $\mathrm{pH}$ of each fraction $(2.25 \mathrm{ml})$ was measured at $5^{\circ} \mathrm{C}$ with a Pye model $290 \mathrm{pH}-\mathrm{meter}$ and a Pye-Ingold spear combined electrode type 401-M5. The enzyme activity in each fraction was determined by diluting a $0.1 \mathrm{ml}$ sample with $0.9 \mathrm{ml}$ of the appropriate buffer and incubating it with $1.0 \mathrm{ml}$ of the buffered substrate. 


\section{Results and Discussion}

\section{Purification of testicular and epididymal enzymes}

The $N$-acetylhexosaminidase activities in the ram testis and epididymis were shown to be most stable at $\mathrm{pH}$ 5.0-5.5. Therefore the initial extraction of the soluble activity from these tissues was carried out at $\mathrm{pH}$ 5.0. These crude buffer extracts were fractionated by increasing the concentration of $\left(\mathrm{NH}_{4}\right)_{2} \mathrm{SO}_{4}$ in a stepwise manner (Table 1). For both tissues the majority of the recovered $\mathrm{N}$-acetylhexosaminidase activity was precipitated between 30 and $40 \%$ saturation with $\left(\mathrm{NH}_{4}\right)_{2} \mathrm{SO}_{4}$. Caygill et al. (1966) also found that most of the testicular $N$-acetyl- $\beta$-glucosaminidase was precipitated in this fraction.

$\left(\mathrm{NH}_{4}\right)_{2} \mathrm{SO}_{4}$ was removed from the precipitates obtained between 30 and $40 \%$ saturation by gel filtration on Sephadex G-25 in 10mm-sodium phosphate buffer, pH7.0. After this step the specific activities of the testicular and epididymal enzyme preparations were 3.8 and 2.85 times greater than those in the crude buffer extracts. The heterogeneity of these preparations was examined by ion-exchange chromatography on DEAE-cellulose. Several components with $N$-acetyl- $\beta$-glucosaminidase activity were found in each tissue (Fig. 1). These elution profiles were characteristic of each tissue and reproducible. The fractions corresponding to each component were bulked and stored frozen. After dialysis against the starting elution buffer at $4^{\circ} \mathrm{C}$, all the components were rechromatographed on smaller columns under the same conditions as before (Fig. 2a). A typical distribution of the recovered activity among the various components in each tissue is recorded in Table 2. These results confirm that multiple forms of the enzyme occur and that different forms predominate in the ram testis and epididymis. They also suggest that the single major peaks previously observed in crude homogenates of each tissue by isoelectric focusing may in fact consist of mixtures of closely related forms. Caygill et al. (1966) found two enzymic components in the ram testis by using a stepwise $\mathrm{pH}$ gradient for elution from CM-cellulose. Although there is no information concerning the heterogeneity of ram epididymal $N$-acetyl- $\beta$-glucosaminidase, Leaback \& Walker (1967) and Vikha et al. (1971) have demonstrated two and four forms respectively of the enzyme in the pig epididymis by ion-exchange chromatography.

\section{Characterization of $\mathrm{N}$-acetylhexosaminidase com- ponents}

(a) Isoelectric focusing. The existence of multiple forms of this enzyme in crude extracts of the ram testis and epididymis has previously been demonstrated by isoelectric focusing. Therefore each of the components separated on DEAE-cellulose was analysed by isoelectric focusing to relate the individual components to the isoelectric-focusing profile of the crude tissue extracts. A sample of the enzymic material precipitated from each tissue between 30 and $40 \%$ saturation with $\left(\mathrm{NH}_{4}\right)_{2} \mathrm{SO}_{4}$ was also analysed for comparison. All the individual components gave sharp activity peaks in their focusing profiles (Fig. 2b) and had distinct and reproducible pI values (Table 2). In contrast much broader peaks were observed when crude enzyme preparations were focused.

Table 2 shows that in general the components are

Table 1. $\left(\mathrm{NH}_{4}\right)_{2} \mathrm{SO}_{4}$ fractionation of soluble extracts from ram testis and epididymis

The supernatants from $25 \%(\mathrm{w} / \mathrm{v})$ homogenates of testis $(416 \mathrm{~g})$ and epididymis $(50 \mathrm{~g})$ were fractionated.

Testis

\section{Fraction}

$3000 \mathrm{~g}$ supernatant

0-20\%-satn.-( $\left(\mathrm{NH}_{4}\right)_{2} \mathrm{SO}_{4}$ precipitate

$20-30 \%$-satn.- $\left(\mathrm{NH}_{4}\right)_{2} \mathrm{SO}_{4}$ precipitate

$30-40 \%$-satn.- $\left(\mathrm{NH}_{4}\right)_{2} \mathrm{SO}_{4}$ precipitate

$40-50 \%$-satn- $\left(\mathrm{NH}_{4}\right)_{2} \mathrm{SO}_{4}$ precipitate

$40-50 \%$-satn.- $\left(\mathrm{NH}_{4}\right)_{2} \mathrm{SO}_{4}$ supernatant

Total

Specific
(munits $/ \mathrm{mg}$

\section{Testis}

$/ \mathrm{mg}$ of protein)

18.3

3.1

11.0

66.7

10.0

0.2

Vol. 133

Recovery
$(\%)$
100

0.7

3.2

67.5

7.1

0.3

78.8
Epididymis

\begin{tabular}{cc}
\hline $\begin{array}{c}\text { Specific activity } \\
\text { (munits/mg of protein) }\end{array}$ & $\begin{array}{c}\text { Recovery } \\
(\%)\end{array}$ \\
180 & 100 \\
86 & 1.0 \\
127 & 5.0 \\
480 & 95.6 \\
180 & 2.0 \\
9.2 & 1.0 \\
& 104.6
\end{tabular}




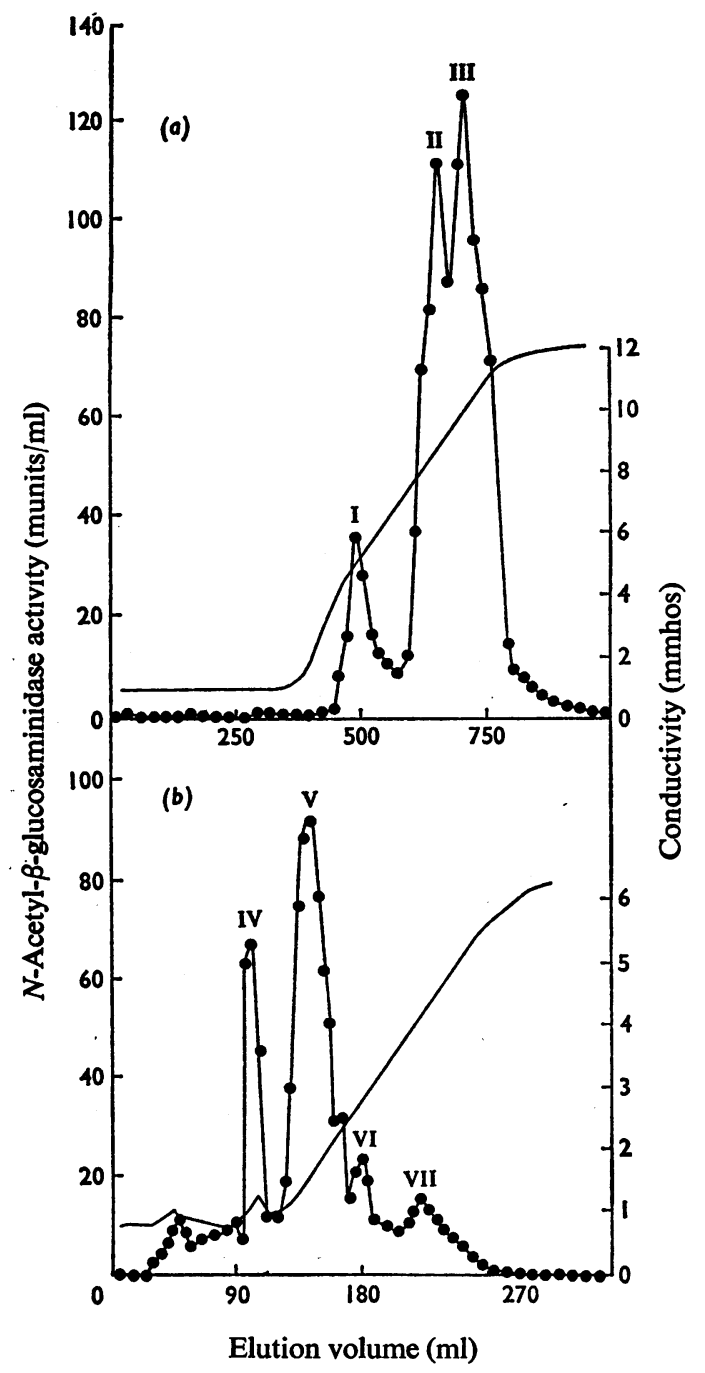

Fig. 1. Chromatography on DEAE-cellulose of testicular and epididymal material precipitated between 30 and $40 \%$ saturation with $\left(\mathrm{NH}_{4}\right)_{2} \mathrm{SO}_{4}$

(a) Testicular protein $(640 \mathrm{mg}$; specific activity 67 munits/mg of protein) was applied to a column $(35 \mathrm{~cm} \times 2.5 \mathrm{~cm}$ diam.) of DEAE-cellulose equilibrated in $10 \mathrm{~mm}$-sodium phosphate buffer, pH7.0. (b) Epididymal protein $(24.2 \mathrm{mg}$, specific activity 480 munits $/ \mathrm{ml}$ ) was applied to a column $(30 \mathrm{~cm} \times$ $1.5 \mathrm{~cm}$ diam.) of DEAE-cellulose equilibrated in $10 \mathrm{~mm}$-sodium phosphate buffer, $\mathrm{pH}$ 7.0. Elution was started with the equilibration buffer and continued with a linear buffer concentration gradient from 10 to $200 \mathrm{~mm}$ for 1 litre $(a)$ and 0.5 litre $(b)$. Fraction sizes were $9 \mathrm{ml}(a)$ and $3.2 \mathrm{ml}(b)$. $\bullet, N$-Acetyl- $\beta$ glucosaminidase activity; cussion of the numbered peaks is in the text.

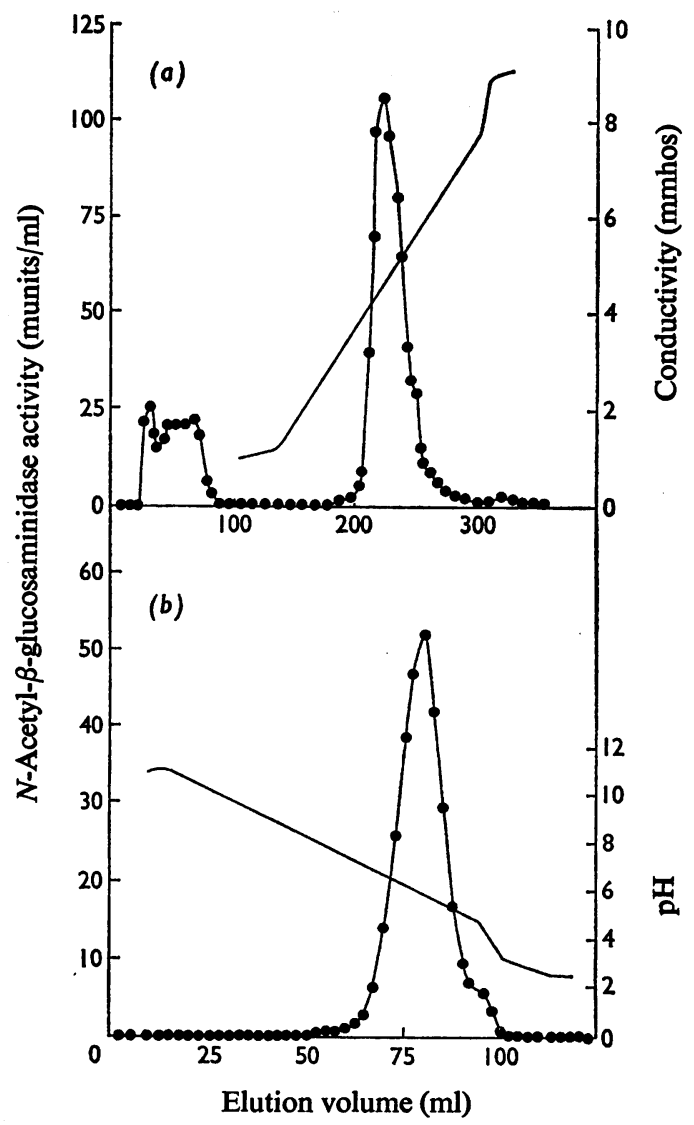

Fig. 2. Analysis of component III by further ionexchange chromatography and by isoelectric focusing

(a) Rechromatography on a column $(30 \mathrm{~cm} \times 1.5 \mathrm{~cm}$ diam.) of DEAE-cellulose. Sample (43.5 mg) had a specific activity of 245 munits/mg of protein. Elution was as for Fig. 1(b). $\bullet, N$-Acetyl- $\beta$-glucosaminidase activity; _- conductivity. (b) Isoelectric focusing over $\mathrm{pH}$ range 5-8. Sample contained $1 \mathrm{mg}$ of protein ( 0.6 unit of activity). Fraction size, $2.25 \mathrm{ml}$. $\bullet$, $N$-Acetyl- $\beta$-glucosaminidase activity; $-\mathrm{pH}$.

eluted from the DEAE-cellulose in order of decreasing pI. It can be seen that components II and III, which account for the majority of the activity in the testis, and are eluted close together from the DEAEcellulose, have very similar pI values, 5.85 and 5.95 respectively. However, previous focusing of crude extracts of testis had indicated that a single major component, $\mathrm{pI}$ value 6.2 , was present. The detection by ion-exchange chromatography of components II and III demonstrates that this major peak is heterogenous and its pI value composite. This $\mathrm{pI}$ value is 
Table 2. Distribution of $N$-acetylhexosaminidase activity among the components separated by chromatography on DEAE-cellulose

The purification factor is the ratio of the specific activity in the bulked fractions corresponding to a component to the specific activity in the original crude homogenate.

$\begin{array}{lcccc} & \text { Component } & \begin{array}{c}\text { \% of recovered } \\ \text { activity }\end{array} & \begin{array}{c}\text { Purification } \\ \text { factor }\end{array} & \text { pI } \\ \text { Testis } & \text { I } & 12 & 50 & 6.45 \\ & \text { II } & 33 & 50 & 5.85 \\ \text { Epididymis } & \text { III } & 47 & 37.5 & 5.95 \\ & \text { IV } & 25 & 31 & 7.15 \\ & \text { V } & 58 & 32 & 7.05 \\ & \text { VI } & 8 & 26 & 6.7 \\ & \text { VII } & 2 & - & 6.1\end{array}$

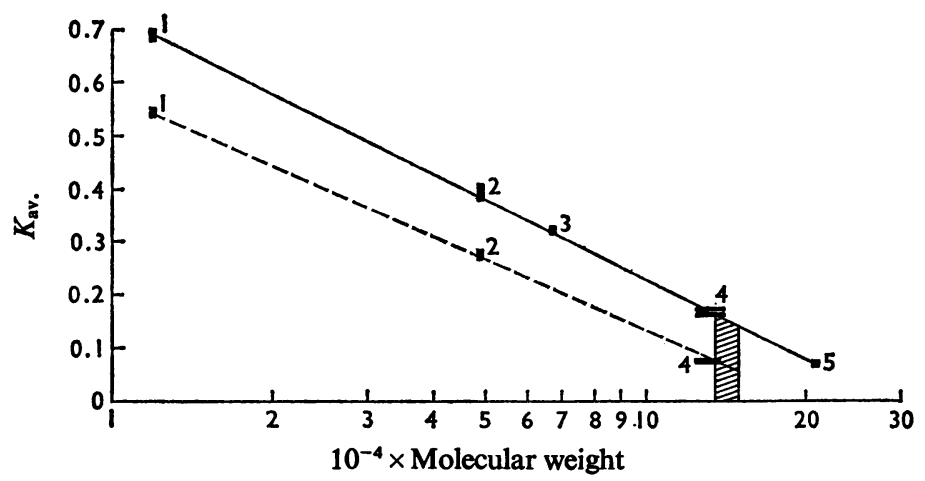

Fig. 3. Estimation of the molecular size of the purified $N$-acetyl- $\beta$-glucosaminidase components by gel filtration on Sephadex G-150 (-) and Bio-Gel P-150 (---)

Full experimental details are given in the Materials and Methods section. The partition coefficients $\left(K_{\mathrm{av}}\right)$ for the samples $(2 \mathrm{ml})$ of all the purified components and mixtures of components fell within the hatched zone shown. Standards are: 1 , cytochrome $c ; 2$, peroxidase; 3 , bovine serum albumin; 4, alkaline phosphatase; 5, $\gamma$-globulin.

slightly higher than those of components II and III ow ing to the presence in the crude extract of component I, pI value 6.45. Further, co-focusing of purified components II and III also gave a single broad peak similar to that obtained from the crude homogenate. Likewise, components IV and V, pI values 7.15 and 7.05 , make up the major peak, pI 7.0, observed on focusing crude extracts of the epididymis.

Isoelectric focusing showed that all the components separated by ion-exchange chromatography were distinct entities which could be characterized by a physical parameter, their $\mathrm{pI}$ value.

Multiple forms of $\mathrm{N}$-acetylhexosaminidase were also shown to occur in ejaculated ram semen by isoelectric focusing. Some of these components had pI values corresponding to forms found in the testis and some to forms found in the epididymis. In addition there were components with lower $\mathrm{pI}$ values which had not been observed previously.

(b) Gel filtration. The homogeneity and molecular weight of each of the components after isoelectric focusing were investigated by gel filtration on Sephadex G-100 and G-150. Samples of the crude tissue extracts and the material precipitated between 30 and $40 \%$ saturation with $\left(\mathrm{NH}_{4}\right)_{2} \mathrm{SO}_{4}$ were also analysed. A single peak of $\mathrm{N}$-acetylhexosaminidase activity was observed in all the experiments. A comparison of the partition coefficients of these peaks with those of the standards showed all the individual components and mixtures of components to have the same molecular weight, $140000 \pm 10000$ (Fig. 3). As this value is near the useful limit of Sephadex G-100 the results were checked on Sephadex G-150.

Vol. 133 
The same result was obtained when the concentration of the elution buffer was decreased from $0.2 \mathrm{M}$ to $50 \mathrm{~mm}$. Some enzymes involved in the transformation of carbohydrates have been reported to be retarded by affinity for the carbohydrate matrix of Sephadex (Andrews, 1970). Therefore Bio-Gel P-150, a polyacrylic compound, was also employed as a gelfiltration medium. However, the same results were obtained (Fig. 3). Thus gross differences in molecular weight do not appear to account for the existence of multiple forms.

(c) Catalytic properties. All the enzymic components purified by the successive steps of ion-exchange chromatography, isoelectric focusing and gel filtration possessed both $N$-acetyl- $\beta$-glucosaminidase and $N$-acetyl- $\beta$-galactosaminidase activity. The pH-dependence of the activities of all components was very similar with the $\mathrm{pH}$ optima for the galactosaminide consistently lower than for the glucosaminide (Table 3). The $\mathrm{pH}$ optima of the purified components were always slightly higher than those obtained for the crude homogenates. Although the $K_{m}$ value for the glucosaminide varied slightly among the components, it was always greater than the corresponding $K_{m}$ for the galactosaminide, which was almost identical for all the components. The maximum velocity for the glucosaminide was three to four times greater than that for the galactosaminide. Thus all of the components have very similar catalytic properties towards synthetic substrates. Vikha et al. (1972) have been unable to differentiate the components in the pig epididymis on the basis of their kinetic behaviour towards synthetic substrates.

\section{Basis of enzymic heterogeneity}

An interesting observation was made concerning the stability of the components separated by ionexchange chromatography. When a component, which had previously been adsorbed on to the DEAE-cellulose and eluted by the buffer gradient, was rechromatographed a certain amount of activity appeared as an unadsorbed breakthrough peak (Fig. $2 a$ ). This was not due to overloading of the column or to disequilibration of the sample or column from the starting buffer. Further, small amounts of activity were usually observed in positions corresponding to components that would be expected to be eluted before the component being rechromatographed, i.e. to components with higher pI values. The unadsorbed breakthrough peak was obtained when all three testicular and four epididymal components were rechromatographed after prolonged storage. Analysis of these breakthrough peaks by isoelectric focusing showed that they consisted predominantly of activity isoelectric between pH7.0-7.3. Minor components in the breakthrough peak, and activity only slightly retarded by the column, had pI values intermediate between this range and the pI of the purified component from which they were derived. This suggests that on storage the purified components are partially converted into other forms and that intermediates are involved in the process. It was observed that the longer the purified components were stored the greater was the conversion into other forms. The $\mathrm{pH}$ optima and kinetic parameters of the activity in these breakthrough peaks were similar to those of the purified components. Gel filtration of these new forms showed that the conversion was not associated with a change in molecular weight. A different surface charge distribution resulting from a change in the protein conformation could explain the increase in pI that occurs on conversion. An alternative explanation could be the loss of a small covalently or non-covalently bound part of the molecule. If this moiety was negatively charged or if its removal exposed a positive charge on the residual molecule, then the pI of the residual molecule would increase. The conversion of one form of human

Table 3. Comparison of the catalytic properties of the purified components

$K_{m}$ and $V$ were measured at pH5.3 and 5.0 for 4-methylumbelliferyl $N$-acetyl- $\beta$-glucosaminide and 4-methylumbelliferyl $N$-acetyl- $\beta$-galactosaminide respectively.

\begin{tabular}{|c|c|c|c|c|c|}
\hline \multirow[b]{2}{*}{ Component } & \multicolumn{2}{|c|}{$N$-Acetyl- $\beta$-glucosaminidase } & \multicolumn{2}{|c|}{$N$-Acetyl- $\beta$-galactosaminidase } & \multirow{2}{*}{$\frac{V_{\text {GleNAc }}}{V_{\text {GaINAc }}}$} \\
\hline & pH optimum & $K_{m}(\mathrm{mM})$ & pH optimum & $K_{m}(\mathrm{~mm})$ & \\
\hline $\mathbf{I}$ & 5.5 & 0.46 & 5.1 & 0.097 & 4 \\
\hline II & 5.8 & 0.26 & 5.3 & 0.098 & 3.5 \\
\hline III & 5.4 & 0.82 & 4.9 & 0.11 & 4.7 \\
\hline IV & 5.8 & 0.68 & 5.0 & 0.1 & 3.0 \\
\hline V & 5.9 & 0.3 & 5.5 & 0.12 & 3.5 \\
\hline VI & 5.8 & 1.43 & 4.9 & 0.104 & 2.7 \\
\hline VII & 5.8 & 0.3 & 5.3 & 0.11 & 2.2 \\
\hline
\end{tabular}


spleen $N$-acetyl- $\beta$-glucosaminidase into another more basic form on treatment with neuraminidase has been attributed to the removal of sialic acid groups (Robinson \& Stirling, 1968). This process also occurs spontaneously in the absence of neuraminidase. Dance et al. (1970) have observed that controlled heat denaturation leads to the conversion of one form of human kidney $\mathrm{N}$-acetylhexosaminidase into another more-basic form with the concomitant appearance of an intermediate form.

Distinct multiple forms of the enzyme account for the $N$-acetylhexosaminidase activity in the ram testis and epididymis. The molecular size and catalytic properties of these multiple forms are very similar. Prolonged storage of dilute solutions of the purified components led to their partial conversion into forms with higher $\mathrm{pI}$ values. Changes in molecular size and catalytic properties were not associated with this conversion. A similar controlled conversion in vivo could explain the existence of multiple forms in the ram testis and epididymis. It could be related to the function and distribution of the multiple forms in these tissues.

We are grateful to the Science Research Council for a Scholarship to S. B. and to Professor D. Robinson for his encouragement and advice.

\section{References}

Andrews, P. (1970) Methods Biochem. Anal. 18, 1-. 53
Caygill, J. C., Roston, C. P. J. \& Jevons, F. R. (1966) Biochem. J. 98, 405-409

Conchie, J. \& Mann, T. (1957) Nature (London) 179, 1190-1191

Conchie, J., Findlay, J. \& Levvy, G. A. (1959a) Nature (London) 183, 615-616

Conchie, J., Findlay, J. \& Levvy, G. A. (1959b) Biochem. J. 71, 318-325

Dance, N., Price, R. G. \& Robinson, D. (1970) Biochim. Biophys. Acta 222, 662-664

Findlay, J. \& Levvy, G. A. (1960) Biochem. J. 77, 170-175

Leaback, D. H. \& Walker, P. G. (1961) Biochem. J. 78, 151-156

Leaback, D. H. \& Walker, P. G. (1967) Biochem. J. 104, $70 \mathrm{P}-71 \mathrm{P}$

Lineweaver, H. \& Burk, D. (1934) J. Amer. Chem. Soc. $56,658-666$

Lowry, O. H., Rosebrough, N. J., Farr, A. L. \& Randall, R. J. (1951) J. Biol. Chem. 193, 265-275

McIlvaine, T. C. (1921) J. Biol. Chem. 49, 183-186

Nicander, L. (1958) Acta Morph. Neerl.-Scand. 1, 337362

Pugh, D. \& Walker, P. G. (1961) J. Histochem. Cytochem. 9, 242-250

Robinson, D. \& Stirling, J. (1968) Biochem. J. 107, 321-327

Vesterberg, O. \& Svensson, H. (1966) Acta Chem. Scand. 20, 820-834

Vikha, G. V., Kaverzneva, E. D. \& Khorlin, A. Ya. (1971) Biokhimiya 36, 33-41

Vikha, G. V., Kaverzneva, E. D., Schulman, M. L. \& Khorlin, A. Ya. (1972) Biokhimiya 37, 322-329

Winchester, B. G. (1971) Biochem. J. 124, 929-934 